\title{
ナノインプリント技術の配線応用に向けたプロセスとモールド設計
}

\author{
尹 成圓 *, 鈴木 健太 *, 廣島 洋*
}

\section{Mold Design and Process for Application of Nanoimprint Lithography to Interconnections}

Sung-Won YOUN*, Kenta SUZUKI*, and Hiroshi HIROSHIMA*

\footnotetext{
* 集積マイクロシステム研究センター（３05-8564 茨城県つくば市並木 1-2-1 産業技術総合研究所 産総研つくば東)

* Ubiquitous MEMS and Micro Engineering Research Center (UMEMSME) National Institute of Advanced Industrial Science and Technology (AIST) (AIST Tsukuba East
} 1-2-1, Namiki, Tsukuba, Ibaraki 305-8564)

\section{1.はじめに}

近年, 集積回路チップの大容量・多接続化や, MEMS な どの異種デバイスとの集積化に対応するため, インター ポーザーを用いた 3 次元積層実装技術が検討されている。 さらなる大容量・多接続化のために 3 次元実装用の配線層 への要求は, 2018 年ベースで $1 \mu \mathrm{m}$ 以下, 2020 年には 500 $\mathrm{nm}$ 以下の線幅の配線形成技術が必要となる展望である。し かしながら, 実装配線は低コストでなくてはならず, 先端 LSI 製造に使用される半導体露光装置（数十億円規模）を 導入することは困難となっているため, 2020 年以降のパ ターン形成技術が空白となっている。

ナノインプリントリソグラフィ (NIL) 技術やは微細なパ ターンが刻まれたモールドを樹脂に押しつけ, 反転形状を 刻む方式の低コストのナノ加工技術である。高生産性, 高 解像性能を有する技術として期待され，2013 年版国際半導 体技術ロードマップ (ITRS) の中で次世代リソグラフィ技術 の候補に挙げられている。これまでは，ある程度の欠陷が 許容される繰り返しパターンで構成された部材（反射防止 フィルム, 細胞培養シート, HDD パターンドメディア, LED 用の微細加工など）への応用が拡がっており, モール ドの大面積化が進むことで，その用途はさらに拡大してい る。実装配線構造を大面積でナノインプリントリソグラ フィすることにより，低コストでのサブミクロンスケール 配線を伴う 3 次元積層実装技術が実現できる。著書らはこ の利点に着目し, ナノインプリント技術の配線形成などの 実装技術への適用について調查検討を進めてきた。本稿で は, ナノインプリント技術の配線応用に向けたモールド設 計とプロセスに関する研究への著書らの取り組みついて紹 介する。特にNILにおいて課題となっている気泡欠陥を防 止する特殊ガス雲囲気下でのナノインプリント技術と, NIL 用のモールド設計ソフトウェアの開発について述べる。

\section{2. 特殊ガス雾囲気下でのナノインプリント技術}

NIL 技術は熱ナノインプリントリソグラフィ (T-NIL) と 光ナノインプリントリソグラフィ (UV-NIL) に大別される。 その中, UV-NIL は常温・低圧インプリントプロセスであ り，高位置合わせ精度，低熱残留応力，高生産性など，実 装配線応用に適した特性を有する。しかし，プロセスメ リットである低成形圧は，大気中インプリント成形におい て残留気泡発生の原因にもなる。真空プロセスが一般的な 解決法であるが，その場合，真空専用のプロセス関連デバ イスおよび治具をすべて真空チャンバー内に設置する必要 があるので, 装置の大きさと值段が大幅に増加する問題が ある。UV-NIL においての気泡欠陥対策として，ポリジメ チルシロキサン (PDMS), ポーラス金属など，酸素透過性 に優れた素材で作製したモールドが用いられている。しか し，ポーラス金属モールドはマイクロレベルパターンへの 適用は可能であるが, ナノパターンへの適用は困難であ る。また, PDMS は柔らかく, 紫外線露光による劣化問題 があるため, ナノパターンの大量作製には適していない。

そこで，著書らは石英モールドを用いたUV-NILにおけ る気泡欠陥を防ぐ方法として，1,1,1,3,3-Pentafluoropropane (HFC-245fa, PFP) ガスやなどの凝縮性ガスを用いた UV-NIL

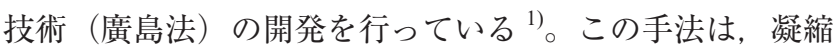
性ガスを導入することにより，大気濃度が低い雲囲気下で ナノインプリントを行う。モールドキャビティ内に捕獲さ れた凝縮性ガスは, インプリントの加圧により凝縮・液化 し, UV 硬化性樹脂樹液中へ溶解することにより気泡欠陥 を生じさせない。PFP ガスは室温での飽和蒸気圧が 0.15 $\mathrm{MPa}$ であり, インプリントのプロセス圧力と微細パターン においては毛細管力が生じるため, 一般的な UV-NIL の圧 力条件下で十分な凝縮効果が得られる。PFP ガスは毒劇物 ではなく, 特定化学物質にも該当しない。気泡欠陥の防止 以外の特徴として, UV 硬化性樹脂樹液のモールドキャビ ティ内への高速充填性やモールドの離型性向上が利点とし 
て挙げられる一方で, ナノインプリントした樹脂パターン のパターン高さの減少や, 表面粗さの増大などの副作用な どが実験的にわかっている ${ }^{2)}$ 。そこで, パターン高さの減 少や, 表面粗さの増大を改善する一つの手法として, 本稿 では凝縮性ガスとヘリウム $(\mathrm{He})$ ガスを混合させる手法に関 して紹介する。

$\mathrm{He}$ ガスは, 動的分子径が小さく，モールドの部材となる 石英の細孔を通り抜けることができるために, He ガス雲囲 気下でNIL を行う手法は, 気泡欠楩防止する別の方法とし て報告されている ${ }^{3)}$ 。今回われわれは, 凝縮性ガスに $\mathrm{He}$ を 混合させることにより, 樹脂の充填性やパターンの表面粗 さに関してどのような影響が生じるかに関して調查を行っ た ${ }^{4)}$

キャビテイ深さ $94 \mathrm{~nm}$, 幅 $100 \mu \mathrm{m}$ のチェッカーパターン が全表面に形成された石英モールを用い，大気， He, PFP ガスの異なる雲囲気中で作製した UV-NIL サンプルを図 1 に示す。成形素材としては約 Si ウェハ上に回転塗布された $65 \mathrm{~nm}$ 膜厚の PAK-01 を用いた。インプリント圧力は 0.1 $\mathrm{MPa}$, 露光時間は 1 秒 $\left(100 \mathrm{~mW} / \mathrm{cm}^{2}\right)$ であった。モールド表 面は fluoroalkylmethylsiloxane (Gelest AquaphobeTM CF) を用 いて離型処理を行った。大気中では，600 秒以上長くプレ スしても気泡欠陥が無くならないことが観察される（図 1(a)）。一方, He と PFP ガス雲囲気中に扔いて観察領域内

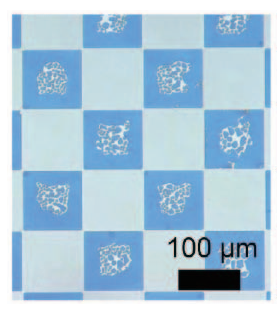

(a) 大気中 成形時間：600 秒

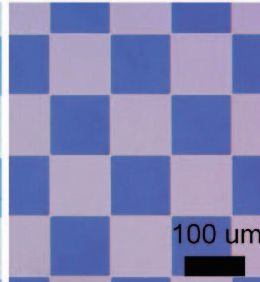

(b) He 2,000 sccm 16.86 秒

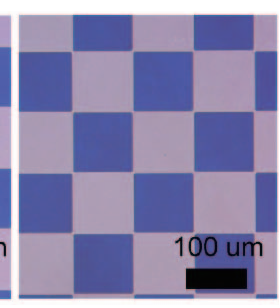

(c) PFP 2,000 sccm 0.13 秒
図 1. 異なる雰囲気ガス中での UV-NIL サンプル (PAK-01/Si)

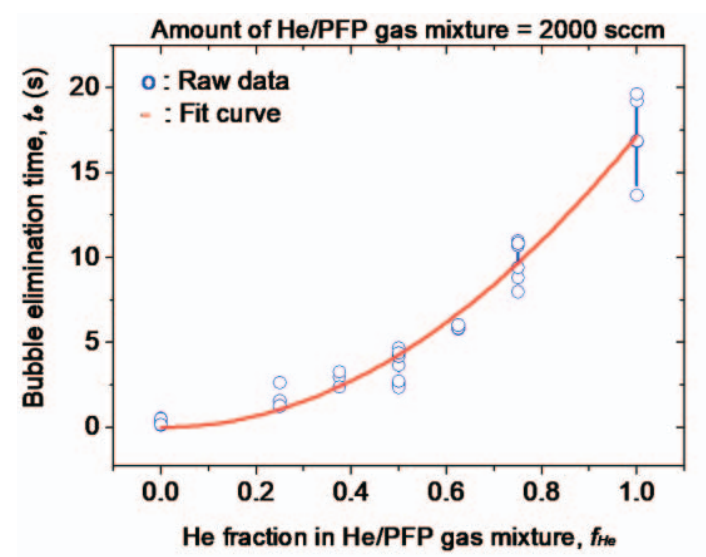

(a) PFP/He 混合ガス雾囲における充填時間
の気泡が消えるのにかかった時間はそれぞれ 16.86 秒と 0.13 秒であり, PFPの方の充填速度が顕著に速いことが分かる (図 1(b), (c))。大気，He，PFP 中での収縮率はそれぞれ $1 \%$, $1 \%, 25 \%$ であった。

図 2 は PFP/He 混合ガスを用いる UV-NIL 工程において, ガス混合比がスループットと表面品質に及ぼす影響を示 す。PFP 雲囲気 (2,000 sccm) 中での UV-NIL は, He 雲囲気 (2,000 sccm) 中の UV-NIL に比べて気泡の除去時間が短いこ とが分かる (PFP: $0.132 \mathrm{~s}, \mathrm{He}: 16.86 \mathrm{~s})$ 。また, He/PFP 混合 ガス $(2,000 \mathrm{sccm})$ 中の $\mathrm{He}$ 比率の上昇に伴い, (1) 気泡除去 時間は 2 次関数的に上昇, (2) 収縮率は減少, 離型力は上昇 (線形に近い形), (3) 表面粗さは減少した。例えば, $\mathrm{He}$ ： $\mathrm{PFP}=1: 3$ の場合, He 環境に比べて 2 倍速い充填速度で高 品質のサンプルが得られることが観察された。

\section{NIL 用のモールド設計ソフトウェアの開発}

インプリントパターンは下部基板へのエッチトランス ファー用のレジストパターンとして用いられる。そのた め，NILによりモールドの反転形状を高い忠実度で基板に 転写作製するだけでなく，インプリント残膜†を薄く，均

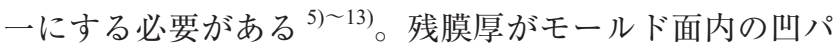
ターンの密度に強く依存することに着目し, いくつかの解 決策が報告されている。一つはインクジェットシステムを 用い，基板に供給する樹脂液滴の体積をパターン密度に合 わせて調整する方式である9)。この方式の有効性は既に確 認されているが, 成形材料である樹脂が低粘度に限られる ことや，高価のインクジェットシステム，モールドおよび インクジェットのマップ情報の管理, プロセス中の複数回 のアライメントなどが必要であり, 利用は容易ではなく, 最先端半導体製造などの特殊な装置にのみ採用されてい る。一方, 汎用性が高い回転塗布膜を用いる NIL では, 残 膜厚の均一化のために，パターンの再配置またはデバイス パターンの周辺にダミーパターンを追加することにより,

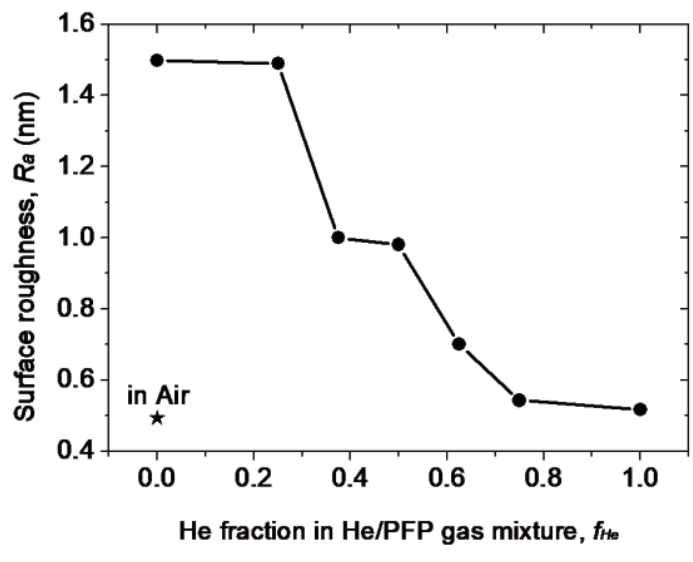

(b) PFP/He 混合ガス雾囲とラフネスの関係

図 2.PFP/He 混合ガスを用いた UV-NIL 
面内パターン密度を一定にする方法がとられていた ${ }^{5), 13) 。 ~}$ ただし，この方法はパターンデザインの変更が許容される 場合のみ適用できる。著者らは, 回転塗布膜を用いる UV-NIL での対策として, パターン密度に応じてモールド の溝の深さを変調することで単位面積あたりの容積をモー ルドの領域によらず均一化する容積均一化手法を提案し

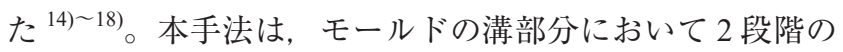
深さの割合をパターン密度に合わせて調整してモールドを 作り込むことにより，モールドの溝の容積を一定にする方 式であり，パターン密度の種類に関わらず， 2 段の深さを 適当な比率で混在させることによって容積の均一化が行え る。この手法の有効性は 2 段の深さを実現するための補助 パターンの作成が容易な, パターン密度が異なる単純なラ イン形状からなるテストパターンにおいて予備的に実証し た。しかし，実際のデバイスパターンなどではパターンが 複雑であり, 手入力で補助パターンを作成することはでき ず。方法論的には可能であるが, 実際には手法を適用する ことができなかった。

本稿では, 容積均一化モールドの概念に基づいた簡便で 柔軟な設計手法の構築を目的に, 元モールドパターンから 容積均一化用の加工パターンデータを自動生成するため のプログラム (Stamp Topography Automated Modification Program, STAMP) の開発やチップスケール補正への適用,

またシミュレーションツールを用いた基礎検証について述 ベる ${ }^{19)}$ 。

\section{1 モールドパターン補正の基本原理}

容積均一化の基本原理を図 3 に示す。図 3(a) は密度が異 なる 3 つの領域（領域 I, II, および III）で構成されている 補正前のモールドデザイン例を示す。図 1(b) に示すよう に, 深さが一定で長さが異なる 2 段目の補正パターンを混 在させることにより, 単位面積あたりの容積を均一化させ る。補正パターンのエッチング深さ $\left(d_{2 e}\right)$ は, 次の関係から 決められる。

$$
\begin{aligned}
& d_{2 e}=d_{1} \times R \\
& R=\frac{A_{\max }}{A_{\min }}-1
\end{aligned}
$$

と表せる。ここで, $d_{1}$ は元パターンの深さで, $R$ は最大パ ターン密度 $\left(A_{\max }\right)$ と最小パターン密度 $\left(A_{\min }\right)$ の比である。

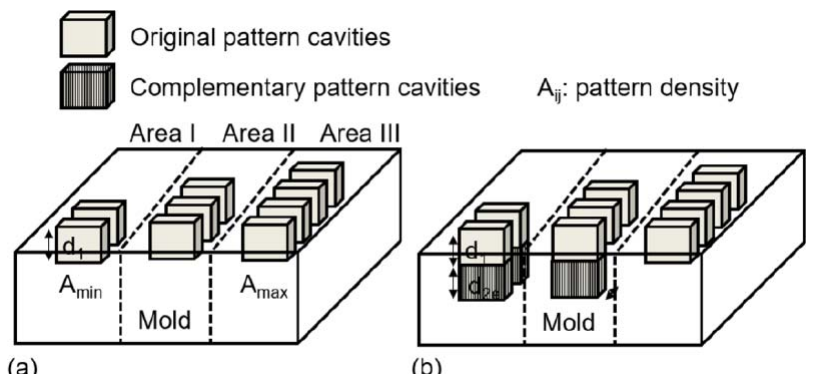

(a)

(b)
図 4 は開発中のモールドパターン補正プログラムを用い た図面の変換例を示す。第 1 ステップとして，モールドパ ターン図面をユーザ指定の基本セルグループに分割し, 各 セルにおけるパターンの面積比 $\left(A_{i j}\right)$ を計算する。ここで, 補正のための単位セルの長さ（または面積）は粒度 $(\mathrm{G})$ と 呼ばれ，インプリント中の補正パターンのエッチング深さ および変形特性（例えば，キャビティ充填時間）に大きい 影響を及ぼす重要な因子の 1 つである。式(1)と (2) で示す ように, 補正パターンのエッチング深さ $d_{2 e}$ は $R$ に比例す るため, 得られた $R$ がユーザ定義の加工限界範囲 $\left(R_{\text {limit }}\right)$ 内 に入るまで異なる粒度にて再分割を行う。次いて, 既存パ ターン上に重量パターンを生成させるため, 補助パターン のサイズを増減しながら, 式 (3) の関係が満たされるまで ブーリアン演算を繰り返す。

$$
A_{\max }-E<A_{i j}+R \times B_{i j}<A_{\max }+E
$$

ここで, $B_{i j}$ はセル内の重畳パターンの密度で, $E$ は容積 均一化演算後のパターン密度におけるユーザ定義の許容誤 差である。生成された相補パターンレイアウトは, GDSII フォーマットのファイルとして出力される。

\section{2 粒度の影響}

所望の任意モールドデザインに対して複数の容積均一化 デザインが存在する。複数の候補の中から適切な設計を選 択するにあったて重要な指標の一つは粒度 $(G)$ である。粒 度はインプリント中の補正パターンのエッチング深さおよ び変形特性に強く影響を与える重要なパラメータの一つで あり，成形素材の粘度および補正パターン深さなどを考慮 して決定する。

UV-NIL シミュレーションにより $10 \mathrm{~mm}$ 角の石英モール

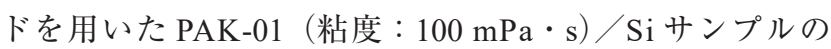
UV-NIL において, 容積均一化効果の粒度依存性を調べた。 UV-NIL 解析には Simprint Nanotechnologies Ltd 社の Simprint Core (ver 4.1) ソフトウェアを用いた。解析に用いた補正前 のモールド表面（厚み $3 \mathrm{~mm}$, サイズ : $1 \mathrm{~cm}$ 角）には $50 \mu \mathrm{m}$ 幅の凹ラインパターンが $0.267,0.500,0.677,0.754$ の密度分 布で配置されている。STAMPソフトウェアを用い，異な

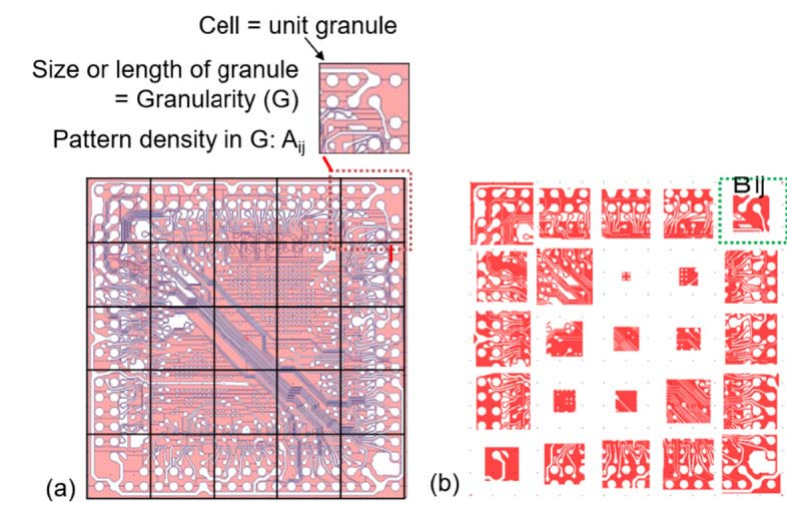

図 4. 容積均一化補正例：(a) 元図面, (b) 補正用の補助図 面例 
る粒度において $(G=48,96,240,320,480,960,1,920,2,400$, $4,800 \mu \mathrm{m}) R$ が一定になるように容積均一化補正用の GDSII 形式の図面を生成し, GDS extractorを用いて解析用ファイ ル形式に変換した。モールド図面を設定粒度に分割し, 各 粒度の面積比 $\left(A_{i j}\right)$ を算出した。 $A_{\text {max }}$ と $A_{\text {min }}$ はそれぞれ 0.267 と 0.754 であり, 式 (2)により計算された $R$ は 1.823 であっ た。元パターン深さ $\left(d_{1}\right)$ が $90 \mathrm{~nm}$ の場合, 式 (1)により, 補正パターンのエッチング深さ $\left(d_{2 e}\right)$ は $147 \mathrm{~nm}$ になるため, 補正された領域のパターン深さ $\left(d_{2}\right)$ は $237 \mathrm{~nm}$ に設定した。 補正前のパターン密度 0.267-0.754 は, 補正により $3 \mathrm{D}$ パ ターン密度 $0.754 \pm 0.01$ に揃えられた。初期層厚は 120 $\mathrm{nm}$, メッシュサイズは $50 \mu \mathrm{m}$ とした。UV-NIL シミュレー ションで計算した $G$ とキャビティ充填時間の関係を図 3 に 示す。容積均一化の原理を考慮し, 完全充填直後 $(P=1)$ に おいて膜厚分布の比較を行った。ここで， $P=1$ は全ての領 域において充填率が 95\% 以上になった時点を示す。充填時 間は粒度のサイズに比例する傾向を示した。また，パター ンの最小寸法 $(50 \mu \mathrm{m})$ より粒度が一定以上大きくないと殘 膜均一化効果が十分に得られないことが分かった。小さな 粒度はインプリント時間を短縮するのには有効であるが, モールドパターンレイアウトによって下限があることが明 らかであった。容積均一化モールドは補正前のモールドに 比べてパターン容量が高いため, より長いインプリント時 間が必要とされたが, モールドが同じ初期層厚で完全に充 填された場合, より薄い残留層が得られた。容積均一化に よる残膜均一化効果は顕著であり, 残膜厚ばらつきの標準 偏差は $1 / 5$ に減少し, 原型の残膜 (RLT) の標準偏差は 12.7 $\mathrm{nm}$ であったのに対し，CE 型の RLT の標準偏差は $2.47 \mathrm{~nm}$ であった。一方, キャビティ充填時間は粒度と $R$ のトレー ドオフであることから， $R$ 值が不均一な場合には別途検討 が必要となる。

\section{3 チップスケール補正と UV-NIL シミュレーション}

図 5 のようにパターンの密度分布や配置が規則的な場 合, 粒度分割後のパターン密度範囲が予測し易いため, 補 正パターンの加工深さの許容範囲と容積均一化を同時に考 慮することが比較的容易である。一方, 図6のようにパ ターンの密度分布範囲が広く, その配置が複雑なデバイス パターンの場合には, 粒度分割後の密度範囲は予測し難 く, 粒度の減少に伴い $R$ が増加する場合が多い。反面, 粒 度が大きすぎると場合, 樹脂の粘度によっては横方向での 流動が十分行われないため, キャビティ内の完全な充填が 得られない場合もあることを考慮し，粒度の上限を決める 必要がある。

STAMPソフトウェアを用いたチップスケール容積均一化 補正例を図 7 に示す。図7(a) は補正前の元モールドパター ンを示す。図 7(b) は $\mathrm{G}=1,400 \mu \mathrm{m}$ の補正パターンを示し, 図 7(c) は元のパターンと補正パターンを重ね合わせた図面 を示す。補正パターン生成のための演算において, 補正後 の 3 次元密度の許容誤差を 0.02 と設定したため, 容積均一 化後の密度範囲は $0.94 \pm 0.02$ であった。 $\mathrm{A}_{\max }, \mathrm{A}_{\min }, \mathrm{R}$ はそ れぞれ 0.36, 0.94, 1.63 であった。元パターン深さ $\left(\mathrm{d}_{1}\right)$ が 90 $\mathrm{nm}$ であったため, 補正パターンのエッチング深さ $\left(\mathrm{d}_{2 \mathrm{e}}\right)$ と 補正された領域のパターン深さ $\left(\mathrm{d}_{2}\right)$ はそれぞれ $147 \mathrm{~nm}$ と 237 nm であった。Intel(R) Core(TM) i7-4770K プロセッサお
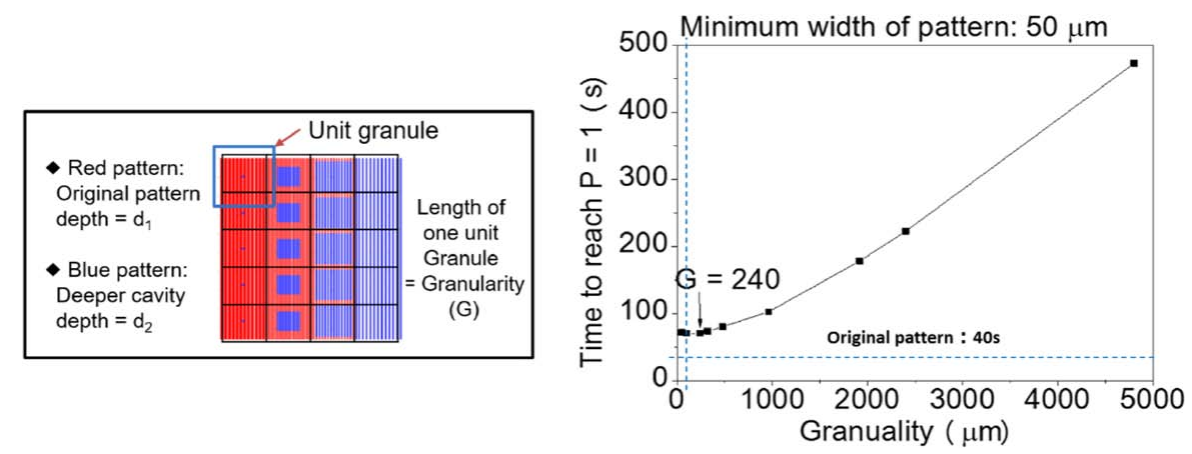

図 5. 充填速度の粒度依存性

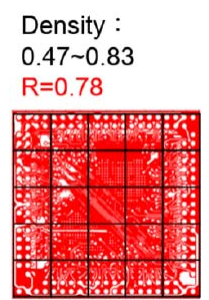

(a) $\mathrm{G}=2800 \mu \mathrm{m}$

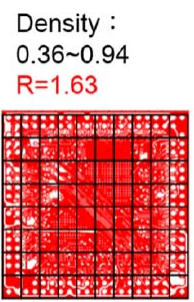

(b) $\mathrm{G}=1400 \mu \mathrm{m}$

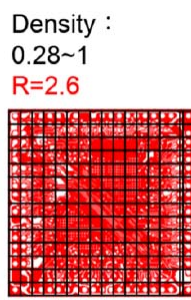

(c) $\mathrm{G}=875 \mu \mathrm{m}$

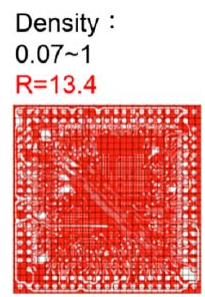

(d) $\mathrm{G}=467 \mu \mathrm{m}$

図 6. 複雑パターンにおいて R 值の粒度依存性

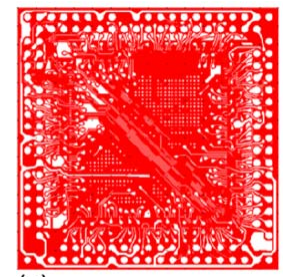

(a)

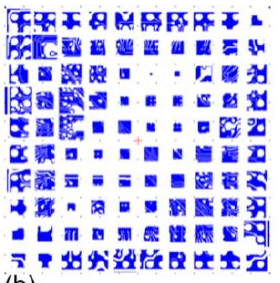

(b)

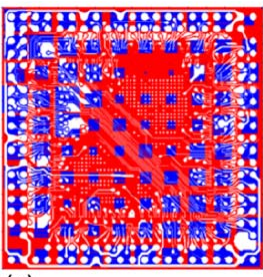

(c)

図 7. チップスケール補正の例 : (a) 元パターン, (b) 補正 用補助パターン, (c) 容積均一化パターン 


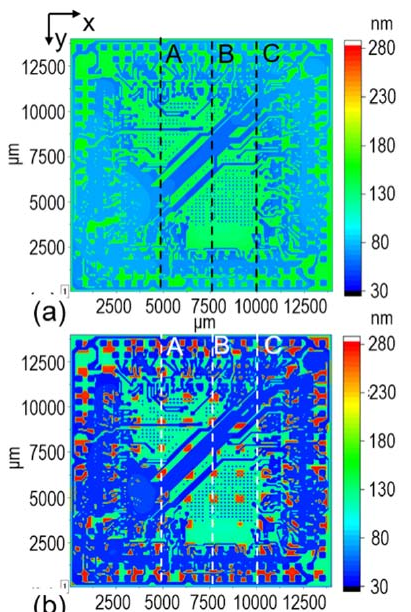

(b) $25005000 \underset{\mu \mathrm{m}}{7500} 1000012500$

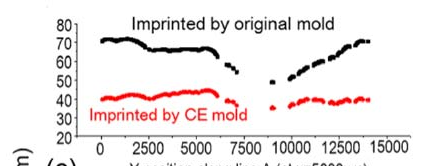

气ิ $(c)$

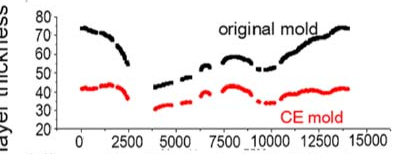

뜬 $(d)$

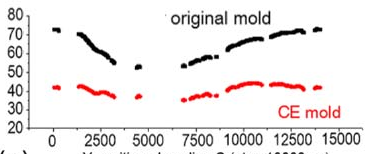

(e) Yposition along line $C$ (at $x=10000 \mu \mathrm{m})$

図 8. (a) 元モールドパターンと (b) 容積均一化モールドに よる UV-NIL 後のサンプルの表面プロファイル。(c)(e) はサンプル面内のラインプロファイルの比較例

よび 32 GB RAM を備えたパーソナルコンピュータを使用 して, 約 $40 \mathrm{Mb}$ サイズの GDSII ファイルを16,384 粒度 $(128 \times 128$ 粒度）に分割し, 容積均一化補正にするのにか かった時間は約 10 分であった。図 7 の図面を用いて行った UV-NIL シミュレーション結果を図 8 に示す。初期層厚と メッシュサイズはそれぞれ $100 \mathrm{~nm}$ と $50 \mu \mathrm{m}$ に設定した。 前述のように, 残膜厚分布の比較には完全充填直後のシ ミュレーションデータを使用した。図 8(a) と図 8(b) は補正 前後のモールドを用いてインプリントを行った場合の充填 終了時の成形領域全域の表面を示す。図 8(a) と (b) の A, B，C 線上でのラインプロファイルの比較を図 8(c)-(e) に 示す。容積均一化による残膜均一化効果は顕著であり, 残 膜厚ばらつきの標準偏差は $1 / 3$ まで低減できていることが 分かる。

\section{4. 結 論}

本稿では，配線応用に向けたナノインプリントプロセス とモールド設計技術について紹介した。

・気泡欠陥フリーの高速パターン形成プロセスの開発を目 的に, $\mathrm{He} / \mathrm{PFP}$ 混合ガスを用いる UV-NIL 工程を提案し, ガス混合比がスループットと表面品質に及ぼす影響を明 らかにした。

・容積均一化モールドの概念に基づいた簡便で柔軟な設計 手法の構築を目的に, 元モールドパターンから容積均一 化用の加工パターンデータを自動生成するためのプログ ラム (STAMP) を開発中である。STAMPソフトウェアに より生成したテストパターンに対して，ナノインプリン 卜成形シミュレーションや実験検証を行い, 残膜厚分布 の標準偏差を $1 / 3-1 / 5$ 低減できることを明らかにした。 信頼性を高めるためには, 容積均一化による残膜均一化 効果はパターンの密度範囲や分布配置に依存するため,

幅広いパターンデザインに対する追加検証が必要である。 今後，上記技術を，MEMS などのマイクロメカトロニク ス実装分野に限らず，微細配線製造技術として幅広く活用 していきたい。

\section{謝 辞}

本研究の成果の一部は JSPS 科研費 16K06035 の助成を受 けたものです。

(2018.12.21- 受理)

\section{文献}

1) H. Hiroshima, H. Atobe, Q. Wang, and S. W. Youn: "UV nanoimprint in pentafluoropropne at a minimal imprint pressure," Jpn. J. Appl. Phys., Vol. 49, 06GL01, 2010

2) S. Kaneko, K. Kobayashi, Y. Tsukidate, H. Hiroshima, S. Matsui, and M. Nakagawa: "Morphological changes in ultravioletnanoimprinted resin patterns caused by ultraviolet-curable resins absorbing pentafluoropropane," Jpn. J. Appl. Phys., Vol. 51, 06FJ05, 2012

3) C. Peroz, S. Dhuey, M. Volger, Y. Wu, D. Olynick, and S. Cabrini: "Bubble-free patterning with low line edge roughness by ultraviolet nanoimprinting using trans-1,3,3,3-tetrafluoropropene condensable gas," Nanotechnology, Vol. 21, 445301, 2010

4) S. W. Youn, K. Suzuki, Q. Wang, and H. Hiroshima: "Control of resin filling and pattern quality of ultraviolet nanoimprint lithography in pentafluoropropane and helium ambient," Jpn. J. Appl. Phys., Vol. 52, 06GJ07, 2013

5) H. Taylor, K. Smistrup, and D. Boning: "Modeling and simulation of stamp deflections in nanoimprint lithography: Exploiting backside grooves to enhance residual layer thickness uniformity," Microelectron. Eng., Vol. 88, pp. 2154-2157, 2011

6) H. Taylor: "Simulation and mitigation of pattern and process dependencies in nanoimprint lithography," J. Photopolym. Sci. Tec., Vol. 24, pp. 47-55, 2011

7) V. Sirotkin, A. Svintsov, S. Zaitsev, and H. Schift: "Viscous flow simulation in nanoimprint using coarse-grain method," Microelectron. Eng., Vol. 83, pp. 880-883, 2006

8) V. Sirotkin, A. Svintsov, S. Zaitsev, and H. Schift: “Coarse-grain simulation of viscous flow and stamp deformation in nanoimprint," J. Vac. Sci. Technol. B, Vol. 28, pp. 2379-2383, 2007

9) S. Merino, A. Retolaza, H. Schift, and V. Trabadelo: “Stamp deformation and its influence on residual layer homogeneity in thermal nanoimprint lithography," Microelectron. Eng., Vol. 85, pp. $877-880,2008$

10) A. Tanabe, T. Uehara, K. Nagase, H. Ikedo, N. Hiroshiba, T. Nakamura, and M. Nakagawa: "Discharge of viscous UV-curable resin droplets by screen printing for UV nanoimprint lithography," Jpn. J. Appl. Phys., Vol. 55, 06GM01, 2016 
11) H. Schmitt, B. Amon, S. Beuer, S. Petersen, M. Rommel, A. J. Bauer, and H. Ryssel: “UV nanoimprint lithography process optimization for electron device manufacturing on nanosized scale," Microelectron. Eng., Vol. 86, pp. 636-638, 2009

12) K. Fukuhara, M. Suzuki, M. Mitsuyasu, T. Komukai, M. Hatano, T. Kono, T. Nakasugi, Y. Lim, W. Jung, and K. Nakamae: "Overlay improvement in nanoimprint lithography for 1x-nm patterning," J. Vac. Sci. Technol. B, Vol. 34, 06K405, 2016

13) F. Lazzarino, C. Gourgon, P. Schiavone, and C. Perret: "Mold deformation in nanoimprint lithography," J. Vac. Sci. Technol. B, Vol. 22, pp. 3318-3322, 2004

14) H. Hiroshima: "Fabrication of capacity-equalized mold for homogenizing residual layer thickness in imprint lithography, Jpn. J. Appl. Phys., Vol. 47, pp. 8098-8100, 2008

15) K. Suzuki, S. W. Youn, Q. Wang, H. Hiroshima, and Y. Nishioka: "Fabrication processes for capacity-equalized mold with fine patterns,” Jpn. J. Appl. Phys., Vol. 50, 06GK04-1, 2011

16) Q. Wang, H. Hiroshima, S. W. Youn, and K. Suzuki: "Effects of granularity of complementary patterns in a capacity-equalized mold used for UV nanoimprint lithography," Jpn. J. Appl. Phys., Vol. 50, 06GK08, 2011

17) Q. Wang, H. Hiroshima, H. Atobe, and S. W. Youn: "Residual layer uniformity using complementary patterns to compensate for pattern density variation in UV nanoimprint lithography," J. Vac. Sci. Technol. B, Vol. 28, C6M125, 2010

18) H. Hiroshima: "Nanoimprint with thin and uniform residual layer for various pattern densities," Microelectron. Eng., Vol. 86, pp. 611-614, 2009

19) S. W. Youn, K. Suzuki, and H. Hiroshima: "Chip-scale pattern modification method for equalizing residual layer thickness in nanoimprint lithography," Jpn. J. Appl. Phys., Vol. 57, 06HG03, 2018

\section{$\dagger$ 用語解説}

ナノインプリント技術 : 微細な凹凸パターンを表面に持 つモールドを樹脂表面に押し込むことによって，ナノ
オーダーの微細パターンを転写する低コスト・高生産 性・高精度なパターン転写技術。光硬化性樹脂を室温 で石英モールドで押し込み，紫外線露光により硬化さ せた後に離型することによりパターンを作製する方法 を光ナノインプリントという。

残膜：ナノインプリントによりパターンを形成した場 合，他のリソグラフィではパターン凹部ではレジスト が完全に除去されているのに対し，ナノインプリント では原理的にパターン凹部にも樹脂が残ってしまう。 この膜を残膜と呼ぶ。

\section{Pentafluoropropane, PFP (ペンタフルオロプロパン)}

ガス : 室温での飽和蒸気圧が $0.15 \mathrm{MPa}$ である凝縮性ガ ス。飽和蒸気圧以上の加圧で体積が 200 分の 1 に減少 し，液化する特徵を有する。

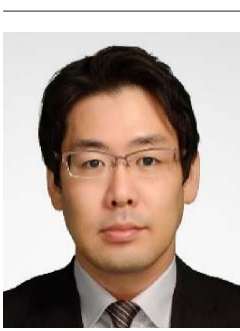

尹成圓 (ゆんそんわん)

著者紹介

国立研究開発法人 産業技術総合研究所 集積又 イクロシステム研究センター 主任研究員 光，熱ナノインプリント, MEMS 実装技術の研究 開発に従事

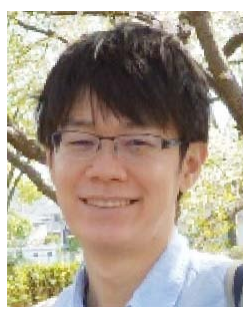

鈴木健太（すずきけんた）

国立研究開発法人 産業技術総合研究所 集積、 イクロシステム研究センター 主任研究員 光，熱ナノインプリント，MEMS 実装技術の研究 開発に従事

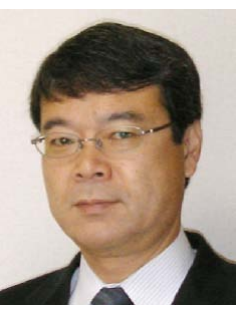

廣島 洋（ひろしま ひろし）

国立研究開発法人 産業技術総合研究所 集積又 イクロシステム研究センター 研究センター長 イオンビームリソグラフィ, 光ナノインプリント 技術の研究開発に従事 